Original Research

\title{
Contaminant Removal and Optimal Operation of Bio-Slow Sand Filtration Water Treatment Based on Nature-Based Solutions
}

\author{
Jie Liu ${ }^{1,2}$, Laisheng Liu³, Zhaoming Huang ${ }^{1 *}$, Yicheng Fu ${ }^{3}$, Zhihua Huang ${ }^{3}$ \\ 'Department of Education and Rehabilitation, Faculty of Education, East China Normal University, Shanghai, China \\ ${ }^{2}$ Department of Rehabilitation, Shanghai General Hosptial, Shanghai Jiaotong University, Shanghai, China \\ ${ }^{3}$ State Key Laboratory of Simulation and Regulation of River Basin Water Cycle, China Institute of Water Resources \\ and Hydropower Research, Beijing, China
}

Received: 16 January 2019

Accepted: 29 May 2019

\begin{abstract}
The nature-based solutions (NBS) concept is closely related to sustainability, harmonious and green development, resource rational exploitation, coupled human health and environment, and ecological protection priority. Bio-slow sand filtration (BSSF) technology is a green water treatment technology with low energy consumption, simple operation, and a high removal rate of contaminants. To achieve low cost, easy management and secondary pollution avoidance in the process of removing contaminants in drinking water, the rational selection of biofiltration materials and the optimal combination of particle size are particularly important based on NBS. To effectively remove turbidity, organic pollutants, bacteria, and ammonia nitrogen by BSSF, three scenarios were summarized by considering the influence of sensitive parameter optimization and the external environment (temperature and velocity). We designed three BSSF water treatment testing devices, which were filled with bio-filter materials with different particle sizes $(0.15-0.3 \mathrm{~mm}, 0.3-0.9 \mathrm{~mm}, 0.9-1.35 \mathrm{~mm}$, and 0.3-0.9 mm), to carry out an indoor testing comparison analysis. We optimized important parameters of BSSF water treatment technology (such as the bio-filter material particle size and filling heights, filtering velocity, and suitable temperature) to obtain the best design and operational parameters of BSSF water treatment technology. The optimum operating conditions were: filter material particle size of 0.3-0.6 mm, filling height of 0.6-0.9 m, filtering velocity of $0.2-0.6 \mathrm{~m} / \mathrm{h}$, and a suitable temperature of $15-35^{\circ} \mathrm{C}$. To ensure the water quality of the filtered water, we optimized the design parameters of traditional BSSF technology, which could save land and reduce beginning time. BSSF water treatment technology based on NBS is useful for promoting the engineering application of drinking water treatment and regional water security.
\end{abstract}

Keywords: nature-based solutions, bio-slow sand filtration, water treatment, parameter optimization

*e-mail: zhaoming_huang@hotmail.com 


\section{Introduction}

An excessive amount of ammonia nitrogen and contaminated bacteria in river banks has caused numerous problems, such as the deterioration of water quality indexes and various health issues. When appropriately treated and recycled, wastewater can become a feasible option as a water source, which could reduce environmental impacts [1]. The bio-slow sand filtration (BSSF) method was conceptualized in Great Britain in 1804. BSSF is a well-known process for drinking water treatment and is widely used by a number of countries in the world, especially developing countries [2]. As a newer method of water treatment technology, BSSF based on nature-based solutions (NBS) was used in tandem with other systems [3]. BSSF has been used for the treatment of high-quality surface waters as well as for the treatment of secondary effluents [4-6].

The nature-based solutions (NBS) could help the recovery of cognitive natural resources and wellbeing [7]. The criteria of NBS have been found in examples of coastal management and the restoration of floodplains [8]. To remove relevant foulants from treated wastewater, different pre-treatment processes have been investigated. To date, filter design and operation have mostly relied on experiences gained in the lab and at full scales over the last centuries [9]. The factors affecting the treatment effect of BSSF technology generally include the bio-filter material particle size, the nonuniformity coefficient, filling height, hydraulic retention time, and ambient temperature. To date, filter design and operation have mostly relied on experiences gained in the lab and at full scales over the last centuries. From the study results, the design parameters generally used in the BSSF water treatment process are: a filter material particle size of $0.15-0.3 \mathrm{~mm}$, filtration velocity of $0.1 \mathrm{~m} / \mathrm{h}$, filter material filling height of $90-110 \mathrm{~cm}$, and an ambient temperature of $24-40^{\circ} \mathrm{C}$. Sand filtration has been used for drinking water treatment plants due to its simplicity in design, low maintenance cost and requirement of only basic handling. However, slow filter technology has the following disadvantages: the particle size of the filter material is small and it clogs easily, resulting in a short operation period; the filter velocity is too low, and the cover areas are large; and the project cost is high. To determine the optimum conditions for the maximum removal of contaminants in a slow sand biofilter system, BSSF combines physical filtration, bio-filtration and adsorption, and the purification process is similar to the natural self-purification function based on NBS.

Regarding effluent quality, cost efficacy and operational simplicity, BSSF can be considered one of the most promising post-treatment options. According to the filtration theory, the smaller the effective particle size of a bio-filter material, the better the filtration effect of contaminants. The particle size of a bio-filter material is related to filtration resistance. The smaller the particle size, the larger the filtration resistance and the easier it is to become clogged. In contrast, the larger the particle size of the filter material, the filter bed is not easily clogged, and the water quality is poor. To remove pathogenic microorganisms, $93 \%$ of the sand was in the full range of $0.212-0.425 \mathrm{~mm}$ grain size, and the main fraction had a grain size of $0.425 \mathrm{~mm}$ [6]. The high efficiency of water treatment achieved by BSSF is partly explained by the effective size of the sand $(0.1-0.3 \mathrm{~mm})$ [10]. BSSF technology does not require backwashing. When the filter bed is clogged, only the surface microbial mucosa needs to be removed. Therefore, reducing the filtration resistance means increasing the cyclic period of the reactor and reducing the filter cleaning frequency. Many studies have focused on the fact that the effective particle size of the filter material should be small enough to prevent contaminants from penetrating the filter layer and ensuring that the water quality meets drinking water quality requirements

[11-12]. By reviewing the literature, the effective particle size of the filter material was $0.15-0.35 \mathrm{~mm}$, and the nonuniformity coefficient was $1.5-2.0$, which could improve filter performance [11]. The literature has considered that a slow filter has an effective particle size of $0.15-0.35 \mathrm{~mm}$, a preferred effective particle size of $0.2 \mathrm{~mm}$, and a nonuniformity coefficient of 3-5 [13]. For BSSF technology based on NBS, selecting an appropriate filter material particle size can ensure the quality of the water, reduce the running resistance, extend the cyclic period, and reduce the cleaning frequency of the filter material.

Filter filling height is an important design parameter that affects effluent quality. At the same filtration rate, an increase in the height of the filter bed is equivalent to an extension of the hydraulic retention time, and the efficiency of removing contaminants is enhanced. As a bio-filter, dissolved organic carbon is removed in the upper sand layer within a depth of 1.0-1.5 m, and biodegradable dissolved organic carbon is mainly removed within a $30 \mathrm{~cm}$ depth [14-15]. The higher the filter bed, the more bio-filter material is needed, which increases the cost of a filter material purchase. However, if the filter bed is too low, the effluent quality cannot be guaranteed. Particles of 7-12 $\mu \mathrm{m}$ were removed at a height of $7 \mathrm{~cm}$ above the filter bed [16]. Heller and Brito [17] found that most of the Cryptosporidium sac was removed within $15 \mathrm{~cm}$ above the filter bed, and the removal rate was $80 \%$ and $100 \%$ in the upper 45 $\mathrm{cm}$ and $60 \mathrm{~cm}$, respectively. Studies have shown that microbial function mainly occurs on the surface to $2 \mathrm{~cm}$, and there is also a small amount of microbial activity within $60 \mathrm{~cm}$ below the surface layer. Because the filter bed should be removed after it is clogged, to reduce the frequency of backfilling of the bio-filter material in a slow filter, the filter layer depth was 90$110 \mathrm{~cm}$ [6]. The removal efficiency of BSSF is subject to variable operational conditions, such as the presence, thickness and biological activity of a schmutzdecke and temperature [18]. 
Low temperature not only affects the chemical reaction rate but also the activity of microbial enzymes and the metabolism of microorganisms. BSSF relies on biological effects for the removal of pollutants especially organic matter. Therefore, a suitable ambient temperature is an important operating parameter of a $\mathrm{BSSF}$ reactor. The water temperature affects the viscosity of the water and so on, and affects the physical filtration performance of slow filtration. Water temperature has a great influence on the biological action. In general, for every $10^{\circ} \mathrm{C}$ drop in water temperature, the biochemical reaction rate of microorganisms will decrease by $50 \%$ [19]. Studies have shown that the minimum temperature range for the suitable growth of microorganisms is $10-15^{\circ} \mathrm{C}$, the maximum temperature range is $35-45^{\circ} \mathrm{C}$, and the optimum temperature range is $24-40^{\circ} \mathrm{C}$ [20].

The existing operating parameters of traditional slow filter technology limit its application and development. The removal of these organic foulants in slow sand filters and factors affecting the performance of BSSF were investigated. By setting different operating conditions, we optimized the important parameters that affected the operation of BSSF technology. The objective of this study was to optimize the parameters, such as the bio-filter material particle size and filling height, filtering velocity, and suitable temperature to obtain the best design and operating parameters of BSSF water treatment technology. Our paper shows the positive effects on the environment and health, which should be taken into account when choosing BSSF water treatment technology.

\section{Materials and Methods}

\section{Experimental Equipment}

To study and improve conventional SSF, laboratoryscale SSF columns can be viewed as good surrogates for full-scale systems. The technical flow chart of the SSF device designed especially for this experiment is shown in Fig. 1. The flow diagram represents the important

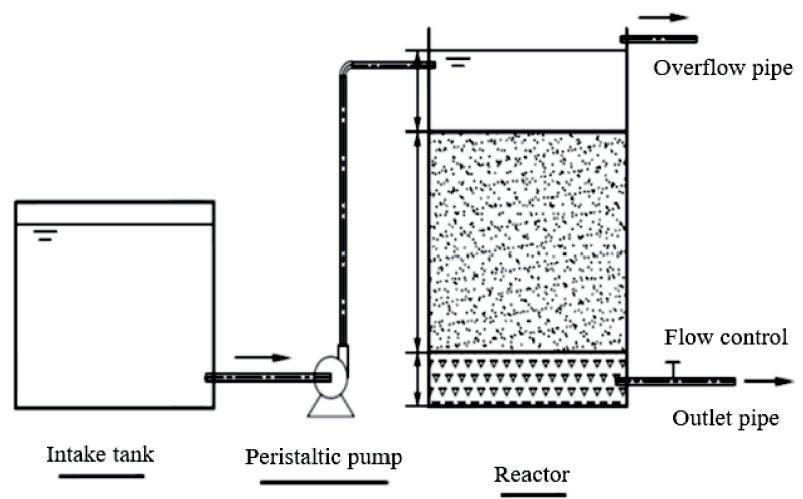

Fig. 1. Schematic representation of the bio-slow sand filtration system.
Table 1. Basic parameters of the quartz sand.

\begin{tabular}{|c|c|c|c|c|}
\hline Number & $\begin{array}{c}\text { Filter } \\
\text { particle size } \\
(\mathrm{mm})\end{array}$ & $\begin{array}{c}\text { Effective } \\
\text { size } \\
\left(d_{10}, \mathrm{~mm}\right)\end{array}$ & $\begin{array}{c}\text { Uniformity } \\
\text { coefficient } \\
\left(d_{60} / d_{10}\right)\end{array}$ & $\begin{array}{c}\text { Grain } \\
\text { porosity } \\
(\%)\end{array}$ \\
\hline $1 \#$ & $0.15-0.30$ & 0.22 & 1.6 & 41.7 \\
\hline $2 \#$ & $0.30-0.90$ & 0.52 & 1.7 & 44.8 \\
\hline $3 \#$ & $0.90-1.35$ & 1.12 & 1.4 & 42.6 \\
\hline
\end{tabular}

features of the pilot experimental setup. The BSSF system contains a filter, a pump, and a sand washing column. Raw water was used as the feed of the BSSF system and overflowed to the storage tank, and the effluent of the experiment equipment was used as the feed of the drinking water.

The column was filled with locally available natural sand. The device included three important components, i.e., an intake tank, a peristaltic pump and a bio-slow sand filtration reactor. The reactor, which was made of organic glass, was the core of the experiment. The inner diameter of the reactor was $0.2 \mathrm{~m}$ and total height was $1.5 \mathrm{~m}$. Three reactors were filled with quartz sand for this experiment. The basic parameters of the quartz for this experiment are shown in Table 1.

\section{Experimental Conditions}

The ambient temperature was $15-25^{\circ} \mathrm{C}$. We used chemical reagents to make up the water for this experiment in the intake tank, and the water quality of the influent for this experiment is shown in Table 2. Each experimental unit had three independent tanks: (1) a nutrient solution storage tank, (2) a drain water tank, and (3) a filtered solution tank [21]. Moreira et al. evaluated BSSF treating synthetic water enriched with Cryptosporidium oocysts and found removal efficiencies between $99.98 \%$ and $99.99 \%$ [22].

Table 2. Experimental water quality

\begin{tabular}{|c|c|c|c|}
\hline Parameter & $\begin{array}{c}\text { Concen- } \\
\text { tration }\end{array}$ & Parameter & $\begin{array}{l}\text { Concentra- } \\
\text { tion }\end{array}$ \\
\hline Turbidity (NTU) & $4.1-8.1$ & $\mathrm{pH}$ & $6.89-7.52$ \\
\hline Chroma & $5-15$ & $\mathrm{DO}(\mathrm{mg} / \mathrm{L})$ & $7.28-11.78$ \\
\hline $\begin{array}{c}\text { Ammonium } \\
\text { nitrogen } / \mathrm{NH}_{4}^{+}-\mathrm{N} \\
(\mathrm{mg} / \mathrm{L})\end{array}$ & $0.13-1.2$ & $\begin{array}{l}\text { Conductivity } \\
(\mu \mathrm{s} / \mathrm{cm})\end{array}$ & $670-920$ \\
\hline $\begin{array}{c}\text { Chemical oxygen } \\
\text { demand/COD }_{\mathrm{Mn}} \\
(\mathrm{mg} / \mathrm{L})\end{array}$ & $3.6-8.2$ & $\begin{array}{c}\text { Coliform } \\
\text { bacteria } \\
(\mathrm{CFU} / 100 \mathrm{~mL})\end{array}$ & $44-151$ \\
\hline $\begin{array}{l}\text { Nitrate/ } \mathrm{NO}_{3}-\mathrm{-N} \\
(\mathrm{mg} / \mathrm{L})\end{array}$ & $0.5-1.2$ & $\begin{array}{c}\text { Aerobic } \\
\text { bacterial count } \\
(\mathrm{CFU} / \mathrm{mL})\end{array}$ & $400-1600$ \\
\hline
\end{tabular}

Note: CFU is the abbreviation of colony-forming units 


\section{Experimental Methods}

The aim of the present study was to develop a computational model that predicts the removal of contaminants by BSSF in drinking water production under various operational conditions. At the start of each comparative experiment, a sample was taken from the supernatant water and stored at the same temperature as the BSSF system. At regular time intervals, sub-samples were taken from this sample for monitoring the concentration of contaminants. The contaminant concentration and bacterial number change in the aqueous phase were estimated from a linear regression of the log transformed concentrations. A twosite kinetic model described the two types of sites for attachment/detachment. An interaction with kinetic site 1 is characterized by relatively fast attachment and slow detachment, whereas an interaction with kinetic site 2 is characterized by both fast attachment and detachment [18, 23-24]. The equations for one-dimensional transport are as follows:

$\frac{\partial C}{\partial t}+\frac{\rho_{B}}{n}\left(\frac{\partial S_{1}}{\partial t}+\frac{\partial S_{2}}{\partial t}\right)=\alpha_{L} \cdot v \frac{\partial^{2} C}{\partial x^{2}}-v \frac{\partial C}{\partial x}-\mu_{1} C-\mu_{S 1} \frac{\rho_{B}}{n} S_{1}-\mu_{S 2} \frac{\rho_{B}}{n} S_{2}$

$$
\begin{aligned}
& \frac{\rho_{B}}{n} \frac{\partial S_{1}}{\partial t}=k_{a t t 1} \cdot C-k_{\mathrm{det} 1} \cdot \frac{\rho_{B}}{n} \cdot S_{1}-\mu_{S 1} \cdot \frac{\rho_{B}}{n} \cdot S_{1} \\
& \frac{\rho_{B}}{n} \frac{\partial S_{2}}{\partial t}=k_{a t t 2} \cdot C-k_{\operatorname{det} 2} \cdot \frac{\rho_{B}}{n} \cdot S_{2}-\mu_{S 2} \cdot \frac{\rho_{B}}{n} \cdot S_{2}
\end{aligned}
$$

...where $C$ is the concentration of the contaminants/ microorganisms $\left(\mathrm{L}^{-1}\right) ; S$ is the concentration of the attached contaminants/microorganisms $\left(\mathrm{g}^{-1}\right) ; t$ is the time (day); $x$ is the distance (m); $\alpha_{L}$ is the dispersivity $\left(\mathrm{m}^{-1}\right)$; $v$ is the average interstitial water velocity $(\mathrm{m} / \mathrm{day}) ; \beta_{B}$ is the dry bulk density $(\mathrm{g} / \mathrm{L}) ; \mathrm{n}$ is the porosity; $k_{a t t}$ and $k_{d e t}$ are the attachment and detachment rate coefficients, respectively $\left(\right.$ day $\left.^{-1}\right)$; and $\mu_{l}$ and $\mu_{s}$ are the inactivation rate coefficients of the free and attached contaminants/ microorganisms, respectively $\left(\right.$ day $\left.^{-1}\right)$. Subscripts 1 and 2 refer to the two different kinetic sites.

Assuming steady state conditions, the removal of microorganisms by sand filtration can be computed as follows [24]:

$$
\ln \left(\frac{C_{x}}{C_{0}}\right)=\frac{\left(1-\sqrt{1+4 \alpha_{L} \frac{\lambda}{v}}\right)}{2 \alpha_{L}} x
$$

$\ldots$ where $\mathrm{C}_{0}$ is the concentration at $x=0, C_{x}$ is the steady state concentration at the outlet of the BSSF system, $\lambda$ is the overall removal rate coefficient $\left(\right.$ day $\left.^{-1}\right)$, and $\ln \left(C_{x} / C_{0}\right)$ indicates the removal rate of the contaminants/ microorganisms.

For easy calculation, the removal rate formula can be simplified as follows [25]:

$$
\ln \left(\frac{C_{x}}{C_{0}}\right)=-1.5 \frac{1-n}{d_{c}} \alpha \eta_{d p, d c, \mu, T, n} x
$$

...where $\alpha$ is the sticking efficiency, $d_{c}$ is the grain size $(\mathrm{m}), d_{p}$ is the particle size of the contaminants/ microorganisms $(\mathrm{m}), \mu$ is the filtration rate $\left(\mathrm{m}^{-}\right.$day $\left.^{-1}\right)$, $\mathrm{T}$ is the water temperature $\left({ }^{\circ} \mathrm{C}\right), x$ is the filter bed length (m), and $\eta_{d p, d, u, T, n}$ is the single collector efficiency. For the calculation of $\eta_{d p, d c, u, T, n,}$ the colloid filtration theory equations of Tufenkji and Elemilech were used [26].

\section{Filter Material Particle Size Comparative Test}

With the same water supply, filtration rate and ambient temperature, a comparison test of the 1\#, 2\# and 3\# BSSF reactors was carried out. The filtration rate in each of the three reactors was $0.2 \mathrm{~m} / \mathrm{h}$, and the test was run stably for 3 months. We sampled and tested the influent and effluent water quality, including the turbidity, total organic carbon (TOC), ammonia nitrogen, and the total number of colonies. The turbidity was measured by the color spectrophotometric determination method or calibration-compensation method. The TOC and ammonia nitrogen in the BSSF experiment were tested with a Multi N/C 3100 type total organic carbon/total nitrogen analyzer. The smear microscopic counting method was used for rapidly determining the total number of colonies.

\section{Filter Material Filling Height Comparative Test}

With the same water supply, filtration rate and ambient temperature, a pollutants removal efficiency t-test comparison test of the 1\#, 2\# and 3\# BSSF reactors was carried out. Each BSSF reactor had three sampling points of $0.5 \mathrm{~m}, 0.75 \mathrm{~m}$ and $0.9 \mathrm{~m}$. The monitoring indexes included the $\mathrm{COD}_{\mathrm{Mn}}$, total number of colonies, and heavy metal (iron, copper, and cadmium) ions.

\section{Filtration Rate Optimization Test}

The filtration rate of the 2\# BSSF reactor was gradually increased from $0.2 \mathrm{~m} / \mathrm{h}$ to $0.8 \mathrm{~m} / \mathrm{h}$, and the effect of filtration rate on the removal of ammonia nitrogen and the total number of colonies were studied.

\section{Effect of Ambient Temperature on the Sewage Treatment Effect}

The 2\# BSSF reactor was started in winter, the room temperature was approximately $0-10^{\circ} \mathrm{C}$, the filtration rate was set to $0.2 \mathrm{~m} / \mathrm{h}$, and the test was run stably for 3 months. We tested the concentration of $\mathrm{NH}_{4}^{+}-\mathrm{N}$ and $\mathrm{COD}_{\mathrm{Mn}}$ in the influent and effluent to study the effect of ambient temperature on their removal. 


\section{Results and Discussion}

Today, drinking water sources are increasingly polluted, and developed countries such as Europe and the United States have begun to re-recognize slowwater treatment technology, and put the technology after rapid filtration as an effective method to control micro-polluting substances in water. Even in some underdeveloped countries, slow filtration has become a widely used method for human and animal drinking water treatment. China's current drinking water hygiene standards mainly refer to the World Health Organization Guidelines for Drinking Water Quality (2004), the European Union Drinking Water Directive (1998), the U.S. EPA National Standard for Drinking Water Quality (2004), the Russian National Drinking Water Sanitation Standard Edition (2002), and the benchmark for drinking water quality in Japan. The "Standards for drinking water quality" (GB5749-2006) is basically in line with similar standards in international organizations and economically developed countries.

\section{Experimental Study on Particle Size Optimization of the Filter}

\section{Comparison of Turbidity Removal Rates of Different Filter Particle Sizes}

The turbidity limit specified in China's "Standards for drinking water quality" (GB5749-2006) is 1 NTU, and if there are inadequate water sources and water purification techniques, the turbidity limit is 3 NTUs. After 5 days of operation, the turbidity of the 1\#, 2\#, and $3 \#$ reactors could meet the limit of less than 3 NTUs. When the system ran for 20 days, the effluent turbidity was stable below 0.3 NTUs, which was much lower than the standard limit. As shown in Fig. 2, the times required for the $1 \#, 2 \#$, and $3 \#$ reactors to achieve the best removal effect were different, and the order of the time required was $3 \#>2 \#>1 \#$. The removal rate of turbidity is not determined by the mechanical filtration

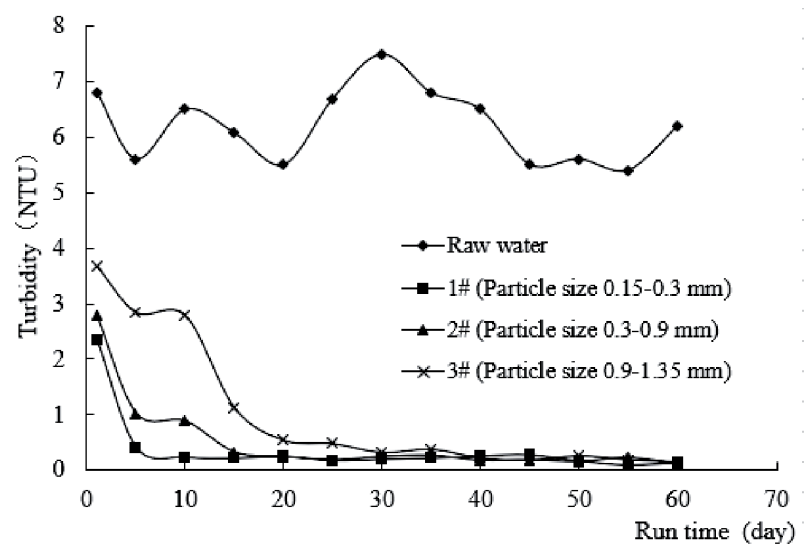

Fig. 2. Removal effect of turbidity by BSSF with different quartz sand sizes.

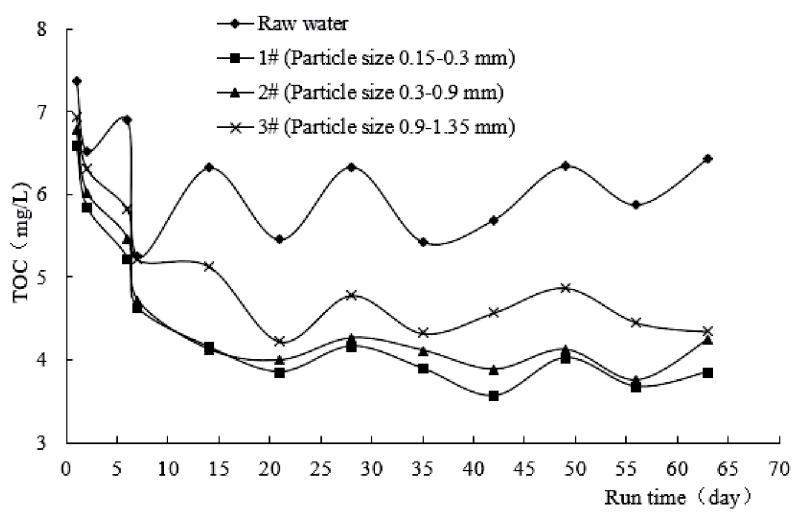

Fig. 3. Removal effect of TOC by BSSF with different quartz sand sizes.

of the filter bed. In the initial stage of the BSSF reactor, the particle size of the different filter materials had a great influence on the removal of turbidity. When the operation was stable, the particle size of the filter had little effect on the removal of turbidity. Slow sand filters reach maturation when the turbidity of the effluent is $<1$ NTU and the removals of both total coliforms and E. coli are higher than $99 \%$ [27].

\section{Comparison of the TOC Removal Rates of Different Filter Particle Sizes}

TOC is a comprehensive index of the organic material content in water. The removal effect of TOC reflects the ability of BSSF technology to degrade organic matter. The removal effect of TOC by BSSF with different quartz sand sizes is shown in Fig. 3. At 5 days after operation, the removal effect of TOC in the $1 \#, 2 \#$, and $3 \#$ reactors were poor, and the removal effect of TOC gradually improved with the extension of the running time. The time required for the $1 \#, 2 \#$, and $3 \#$ reactors to achieve the best removal rate of TOC was different. After 7 days of operation of the 1\# and 2\# reactors, the TOC removal rate reached $10 \%$, and the TOC removal rate reached $20 \%$ after 15 days of operation. After the operation of the \#3 reactor for 20 days, the removal rate reached $5 \%$, and the removal rate of TOC by the $3 \#$ reactor was consistent with the removal rate of the $1 \#$ and $2 \#$ reactors until approximately 60 days of operation. When the microbial mucosa was stable in the reactor, the removal rate of TOC by the three reactors was basically the same.

\section{Comparison of the $\mathrm{NH}_{4}^{+}-\mathrm{N}$ Removal Rates of Different Filter Particle Sizes}

The trend in the $\mathrm{NH}_{4}^{+}-\mathrm{N}$ concentration was similar to that for TOC. The removal effect of $\mathrm{NH}^{4+}-\mathrm{N}$ by BSSF with different quartz sand sizes is shown in Fig. 4. At the beginning of the operation, the removal effect of ammonia nitrogen in the $1 \#, 2 \#$, and $3 \#$ reactors were not significant. As the running time was extended, 


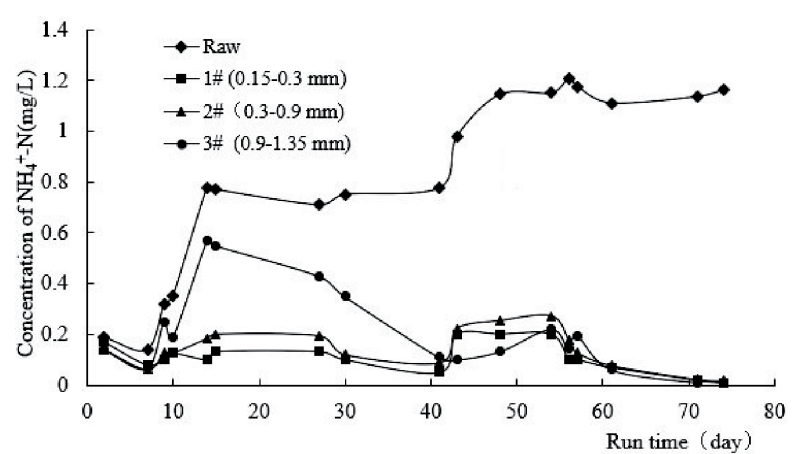

Fig. 4. Removal effect of NH4+-N by BSSF with different quartz sand sizes.

the removal rate of $\mathrm{NH}_{4}^{+}-\mathrm{N}$ was gradually enhanced. The time required for the $1 \#, 2 \#$, and $3 \#$ reactors to achieve optimal $\mathrm{NH}_{4}^{+}-\mathrm{N}$ removal was different. The time required for the optimal removal of $\mathrm{NH}_{4}^{+}-\mathrm{N}$ by the $1 \#$ and $2 \#$ reactors was short (28 days), and the time required for the $3 \#$ reactor was longer (55 days). When the reactor was operated stably, the removal rate of $\mathrm{NH}_{4}^{+}-\mathrm{N}$ in the $1 \#, 2 \#$, and $3 \#$ reactors were basically the same.

\section{Comparison of the Microorganism Removal Rates of Different Filter Particle Sizes}

In the initial stage of operation, the removal rate of microorganisms in the $1 \#, 2 \#$, and $3 \#$ reactors were poor, and a good removal rate was achieved after 20 days of operation. Fig. 5 shows the removal rates of microorganisms by BSSF with different quartz sand sizes. The total number of microorganisms in the effluent of the $1 \#$ and $2 \#$ reactors could meet the limit requirement of $100 \mathrm{CFU} / \mathrm{mL}$ in GB57492006, and the total number of microorganisms in the effluent of the $3 \#$ reactor was higher than that of GB5749-2006 limit requirements. This indicates that the smaller the particle size of the filter material, the better the removal rate of microorganisms by BSSF technology.

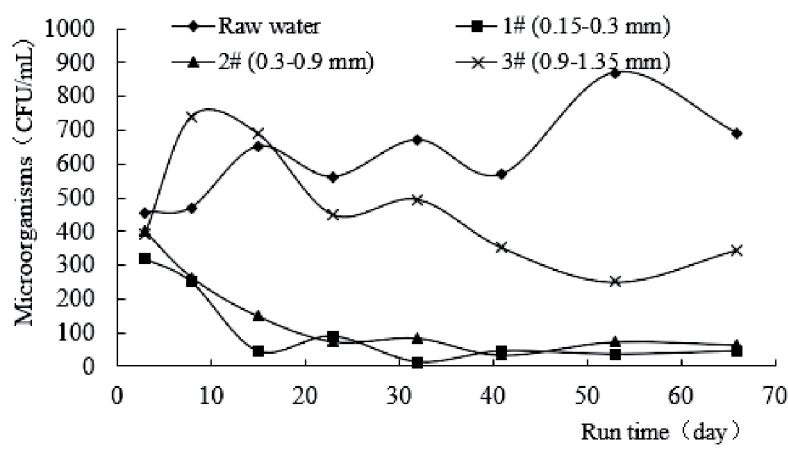

Fig. 5. Removal effect of microorganisms by BSSF with different quartz sand sizes.

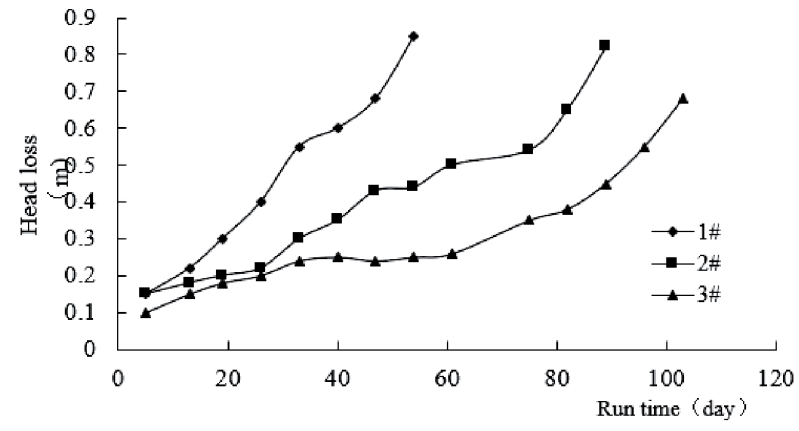

Fig. 6. Relationship of particle size and head loss in BSSF.

\section{Relationship between Particle Size of the Filter Materials and Head Loss}

To further study the influence of the filter material particle size on the filtration process and the removal rate of contaminants, the relationship between the running resistance of the BSSF reactor and the particle size of the filter material was quantified. By extending the cyclic period, we continuously monitored the head loss of the $1 \#, 2 \#$, and $3 \#$ reactors. The results of head loss are shown in Fig. 6. It can be seen from Fig. 6 that when the influent turbidity was less than 10 NTU, the smaller the particle size of the filter material, the larger the head loss and the shorter the reactor cyclic period. Under the same running conditions, the time required for the head loss of the three reactors to reach $0.75 \mathrm{~m}$ was different: the $1 \#$ reactor took 50 days, the $2 \#$ reactor took 85 days, and the $3 \#$ reactor took 100 days.

\section{Experimental Study on the Filling Height Optimization of the Filter Material}

\section{Effect of the Filter Filling Height on the Removal Rate of TOC}

$\mathrm{COD}_{\mathrm{Mn}}$ is an important index of TOC in the reaction water. The removal rate of $\mathrm{COD}_{\mathrm{Mn}}$ can be used to reflect the degradation ability of BSSF technology to TOC. Samples were taken at three positions of 0.5 , 0.75 , and $0.9 \mathrm{~m}$ in the \#1, 2\#, and $3 \#$ reactors, and the concentration of $\mathrm{COD}_{\mathrm{Mn}}$ in the water was measured. As shown in Fig. 7 (a, b, and c), when the 1\# and 2\# reactors were operated for approximately 23 days, the $\mathrm{COD}_{\mathrm{Mn}}$ concentration in the effluent was basically stable; when the $3 \#$ reactor was operated for approximately 32 days, the $\mathrm{COD}_{\mathrm{Mn}}$ concentration in the effluent was substantially stable. This indicates that the maturation time of the microbial mucosa in the $1 \#$ and $2 \#$ reactors was basically the same and was better than that in the $3 \#$ reactor. When the reactor was running stably, the removal rate of $\mathrm{COD}_{\mathrm{Mn}}$ in the $1 \#$ and $2 \#$ reactors was approximately $45-55 \%$, while the removal rate in the $3 \#$ reactor was approximately $30-45 \%$, indicating that the TOC removal rate of the $1 \#$ and $2 \#$ reactors was better 
than that of the $3 \#$ reactor. The difference between the concentration of $\mathrm{COD}_{\mathrm{Mn}}$ in the effluent at the $0.9 \mathrm{~m}$ and $0.5 \mathrm{~m}$ points was $0-6.43 \mathrm{mg} / \mathrm{L}, 1.19-6.27 \mathrm{mg} / \mathrm{L}$, and $3.56-12.75 \mathrm{mg} / \mathrm{L}$ in the $1 \#, 2 \#$, and $3 \#$ reactors, respectively.

The removal rates of $\mathrm{COD}_{\mathrm{Mn}}$ in the effluent of the $1 \#$ and $2 \#$ reactors were higher than that of the $3 \#$ reactor in the $0.5 \mathrm{~m}$ and $0.9 \mathrm{~m}$ height effluent, but the difference between the $\mathrm{COD}_{\mathrm{Mn}}$ concentration in the $0.5 \mathrm{~m}$ height effluent and the $\mathrm{COD}_{\mathrm{Mn}}$ concentration in the $0.9 \mathrm{~m}$ height effluent was less than that in the $3 \#$ reactor. The removal of $\mathrm{COD}_{\mathrm{Mn}}$ in the $1 \#$ and $2 \#$ reactors mainly occurred in the range of $0-0.5 \mathrm{~m}$, which was better than the $3 \#$ reactor in removing $\mathrm{COD}_{\mathrm{Mn}}$. The removal of $\mathrm{COD}_{\mathrm{Mn}}$ mainly utilized the degradation of aerobic microorganisms. The surface microbial mucosa of the $1 \#$ and $2 \#$ reactors was superior to the $3 \#$ reactor. A slow sand filter was found to be efficient in $\mathrm{COD}_{\mathrm{Mn}}$ removal, i.e., a $\mathrm{COD}_{\mathrm{Mn}}$ ranging from 71 to $83 \%$ (avg. 79\%) for the majority of the operational period [28].
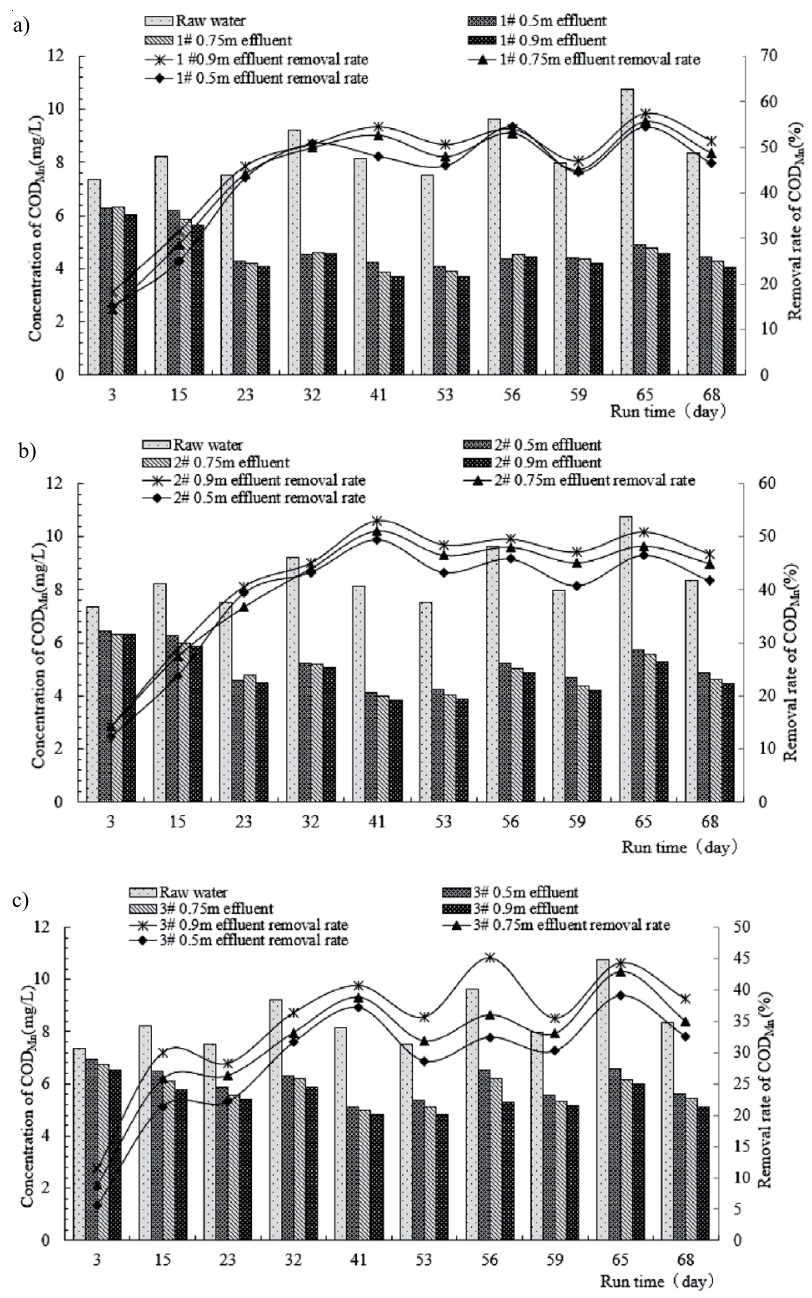

Fig. 7. Relationship between filter filling height and $\mathrm{COD}_{\mathrm{Mn}}$ in the a)1\#, b) 2\#, and c) 3\# BSSF reactors.

\section{Effect of Filter Filling Height \\ on the Removal Rate of Bacteria}

Samples were taken at three positions of $0.5,0.75$, and $0.9 \mathrm{~m}$ in the $1 \#, 2 \#$, and $3 \#$ reactors, and the aerobic bacterial count in the effluent was measured. The results are shown in Fig. 8(a, b, and c). The results showed that the aerobic bacterial count in the effluent at $0.75 \mathrm{~m}$ of the $1 \#$ reactor could basically meet the limit requirements of GB5749-2006, while the colonies of the $2 \#$ and $3 \#$ reactors in the effluent at $0.75 \mathrm{~m}$ did not meet the requirements. The filter filling height should not be less than $0.75 \mathrm{~m}$ with a particle size of $0.15-0.3 \mathrm{~m}$, and the filter filling height should not be less than $0.9 \mathrm{~m}$ with a particle size of 0.3-0.9 $\mathrm{mm}$.

\section{Effect of Filter Filling Height on Removal Rate of Heavy Metals}

To study the effect of BSSF technology on the removal of heavy metals, according to GB5749-2006, the concentration limits of $\mathrm{Cu}^{2+}, \mathrm{Cd}^{2+}$ and $\mathrm{Fe}^{2+}$ are $1.0 \mathrm{mg} / \mathrm{L}, 0.05 \mathrm{mg} / \mathrm{L}, 0.3 \mathrm{mg} / \mathrm{L}$, respectively, and the corresponding metal salt solution was prepared according to the concentration standard of 2 times,
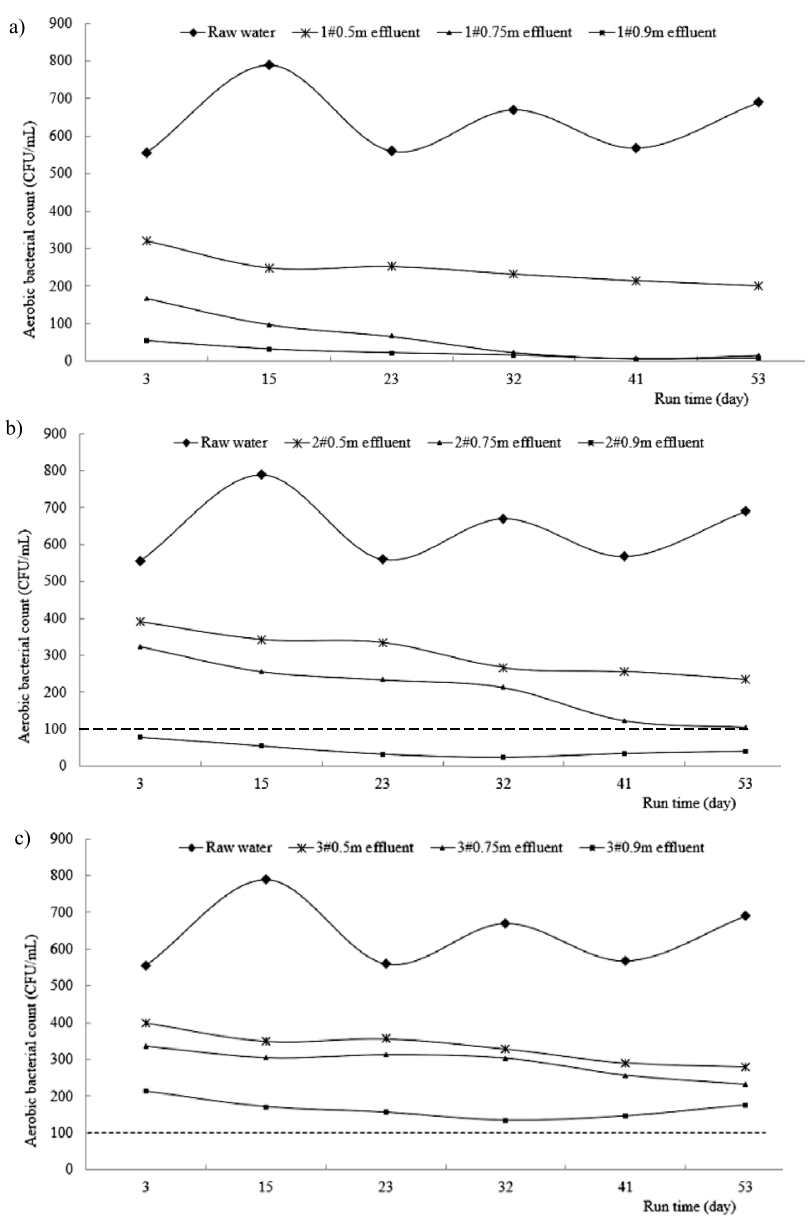

Fig. 8. Relationship between filter filling height and aerobic bacterial count in a)1\#, b) 2\#, and c) 3\# BSSF reactors. 
4 times and 6 times. When the BSSF reactor was stable, the concentration of heavy metal ions in the effluent was sampled at the three positions of the $2 \#$ reactor at $0.5 \mathrm{~m}, 0.75 \mathrm{~m}$, and $0.9 \mathrm{~m}$. The results are shown in Fig. 9(a, b, and c). The results showed that the removal rates of the three heavy metal ions $\left(\mathrm{Cu}^{2+}, \mathrm{Cd}^{2+}\right.$ and $\mathrm{Fe}^{2+}$ ) in the effluent of the $2 \#$ reactor were above $95 \%$, which met the requirements of GB5749-2006. The concentration of the three heavy metal ions in the effluent at $0.5 \mathrm{~m}$ of the $2 \#$ reactor met the requirements of GB5749-2006, and the removal rate of heavy metal ions exceeded $90 \%$. The concentration of heavy metals in the effluent at $0.5 \mathrm{~m}$ in the $2 \#$ reactor was not very different from the concentration of heavy metal ions in the effluent at $0.75 \mathrm{~m}$ and $0.9 \mathrm{~m}$. The removal rate of heavy metals mainly occurred at $0-0.5 \mathrm{~m}$ in the upper layer of the reactor. a)

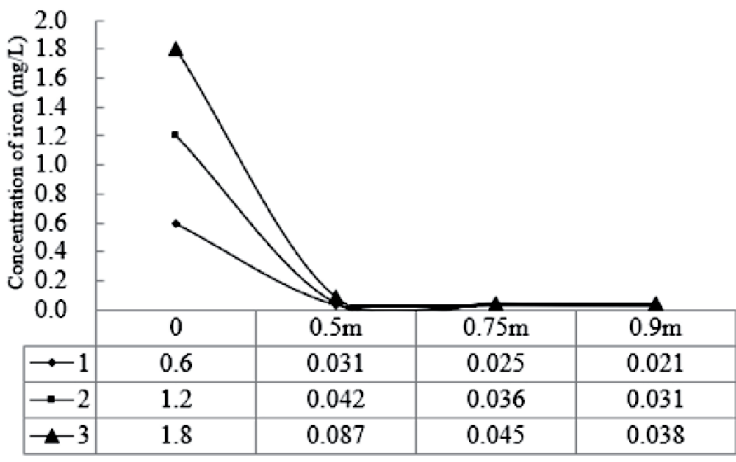

b)

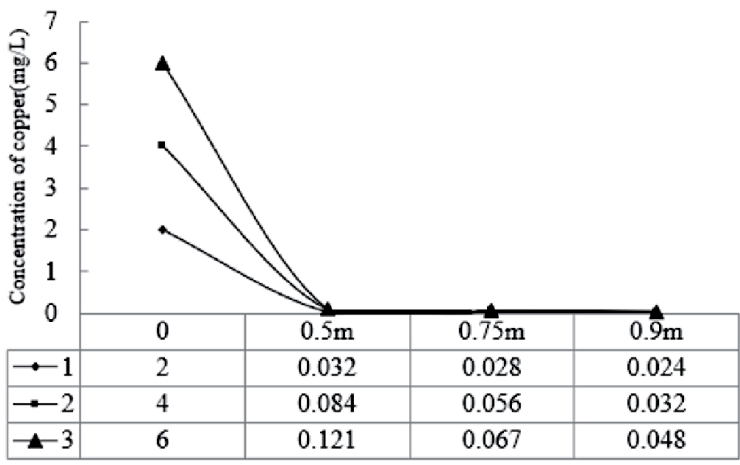

c)

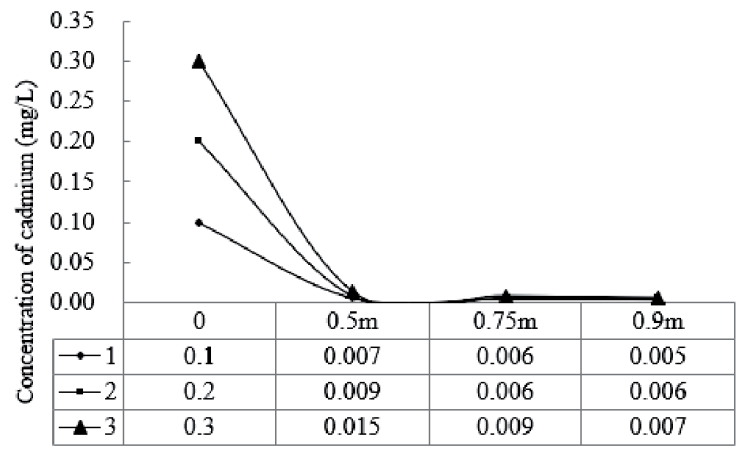

Fig. 9. Relationship between filter filling height and heavy metals in the 2\# BSSF reactor; a) iron, b) copper, c) cadmium.
Effect of the Filtration Rate on Contaminant Removal

Effect of Filtration Rate on the Removal of $\mathrm{NH}_{4}^{+}-\mathrm{N}$

In the test, the filtration rate of the BSSF reactor gradually increased from $0.2 \mathrm{~m} / \mathrm{h}$ to $0.8 \mathrm{~m} / \mathrm{h}$. Fig. 10a) shows that when the filtration rate was in the range of $0.2-0.6 \mathrm{~m} / \mathrm{h}$, the change in the filtration rate had little effect on the removal rate of $\mathrm{NH}_{4}^{+}-\mathrm{N}$. When the filtration rate was greater than $0.6 \mathrm{~m} / \mathrm{h}$, the removal rate of $\mathrm{NH}_{4}^{+}-\mathrm{N}$ decreased as the filtration rate increased. Therefore, to ensure a good removal rate it is recommended that the filtration rate be less than $0.6 \mathrm{~m} / \mathrm{h}$. It can be suggested that higher filtration rates $(10$ and $20 \mathrm{~cm} / \mathrm{h})$ promote the nitrification process transforming ammonium to nitrate, and denitrification microbes could therefore denitrify nitrate to nitrite and then to nitrogen [29].

\section{Effect of Filtration Rate on Removal of Bacteria}

Fig. 10b) shows that when the filtration rate was $0.7 \mathrm{~m} / \mathrm{h}$, the total number of bacteria in the effluent exceeded the limit requirement of GB5749-2006. The recommended filtration rate should be less than $0.6 \mathrm{~m} / \mathrm{h}$. It was predicted that the pathogen reduction efficacy would be reduced during either scenario, with

a)

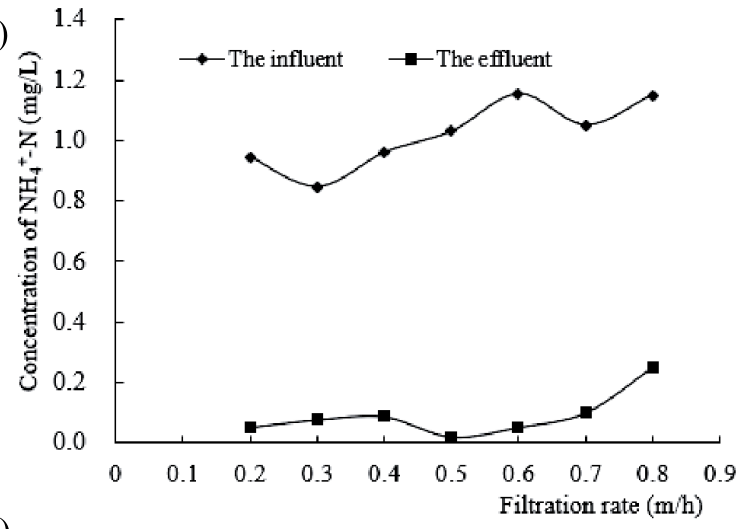

b)

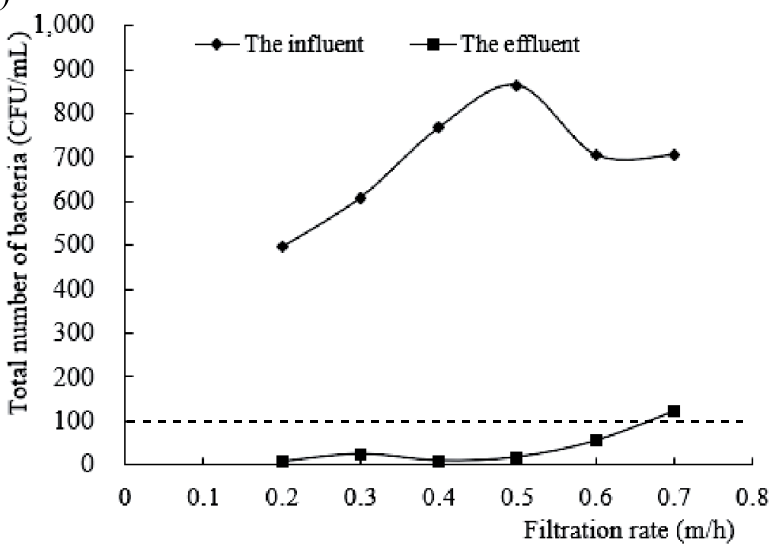

Fig. 10. Relationship between contaminant removal rate and BSSF filtration rate; a) $\mathrm{NH}_{4}^{+}-\mathrm{N}$, b) bacteria. 
the BSSF making a full recovery to its maximum potential reduction efficacy given sufficient time [30]. There was no significant difference between the filters for total coliforms and E. coli removal, but there was considerable difference between sampling times [31].

\section{Effect of Temperature on Contaminant Removal}

\section{Effect of Temperature on $C O D_{M n}$ Removal}

After 35 days for the $2 \#$ reactor, the $\mathrm{COD}_{\mathrm{Mn}}$ concentration of the effluent gradually became stable, and the $\mathrm{COD}_{\mathrm{Mn}}$ removal rate was $25-30 \%$ (Fig. 11a). When the room temperature was $20-35^{\circ} \mathrm{C}$, the removal rate of $\mathrm{COD}_{\mathrm{Mn}}$ in the $2 \#$ reactor was $45-55 \%$. Therefore, a low-temperature condition has a significant effect on the removal effect of $\mathrm{COD}_{\mathrm{Mn}}$. The removal of organic matter is mainly affected by microbial degradation. Lowtemperature conditions severely inhibited the growth, reproduction and degradation of microorganisms in the surface microbial mucosa. The correlation between the $\mathrm{COD}_{\mathrm{Mn}}$ removal and the ambient temperature could be expressed as $(\mathrm{T}+11) / 9$, that is when the temperature was $25^{\circ} \mathrm{C}, \mathrm{COD}_{\mathrm{Mn}}$ removal was $4 \mathrm{mg} / \mathrm{L}$, and when the temperature was $7^{\circ} \mathrm{C}, \mathrm{COD}_{\mathrm{Mn}}$ removal was only $2 \mathrm{mg} / \mathrm{L}$.

\section{Effect of Temperature on $\mathrm{NH}_{4}^{+}-\mathrm{N}$ Removal}

After running for 42 days in the $2 \#$ reactor, the concentration of $\mathrm{NH}_{4}^{+}-\mathrm{N}$ in the effluent could meet

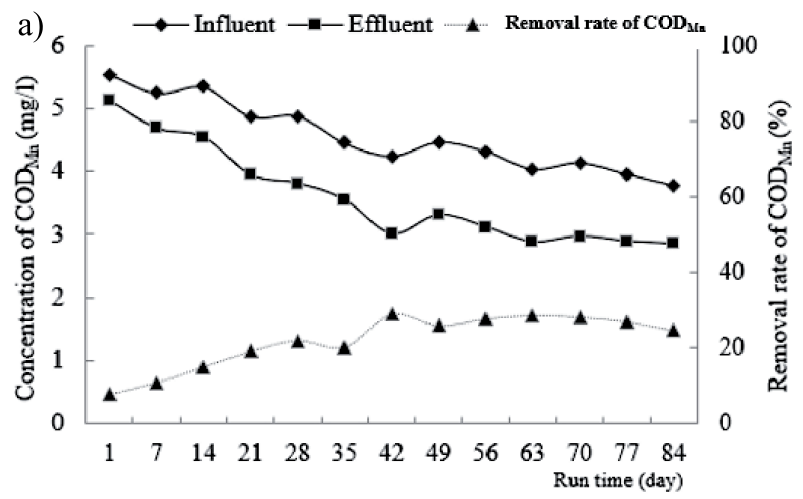

b)

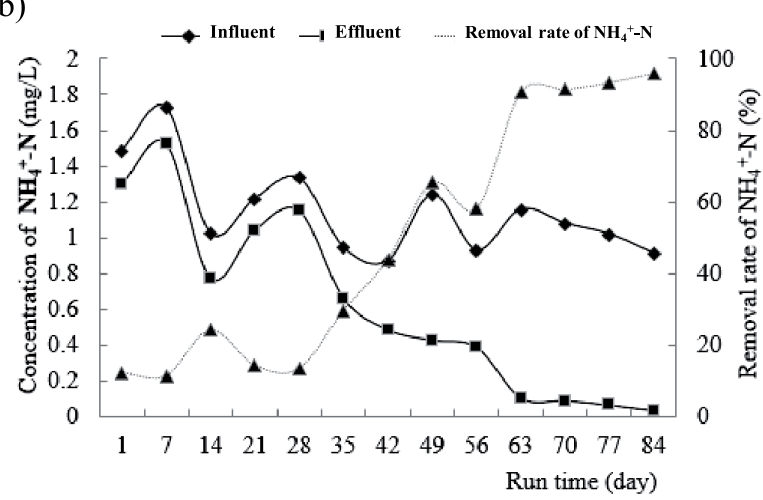

Fig. 11. Contaminants changing with run time at low-temperature conditions; a) $\mathrm{COD}_{\mathrm{Mn}}$, b) $\mathrm{NH}_{4}^{+}-\mathrm{N}$. the limit requirement of $0.5 \mathrm{mg} / \mathrm{L}$ in GB5749-2006 (Fig. 11b). Compared with a room temperature $20-35^{\circ} \mathrm{C}$, the water quality of the reactor after 20 days of operation could meet the standard, indicating that the removal rate of $\mathrm{NH}_{4}^{+}-\mathrm{N}$ was noticeably affected by temperature. The suitable ambient temperature of the $\mathrm{BSSF}$ reactor was preferably maintained above $10^{\circ} \mathrm{C}$. During low-temperature conditions in winter, the BSSF system should adopt a heating preservation measure. Helmreich and Horn [32] stated that the efficiency of sand filters is preferentially oriented for the removal of contamination.

\section{Discussion}

Operational conditions affect the performance of BSSF filtering effluent. Lower filtration rates lead to an improved performance of BSSF with respect to contaminant removal and hydraulic retention time. Temperature and contaminant concentration in the effluent have a comprehensive influence on the performance of BSSF. Higher temperature $\left(>10^{\circ} \mathrm{C}\right)$ or lower contaminant concentration results in more effective removal when contaminant content in the feedwater is comparatively low. Under low temperature and/or high contaminant load, the performance of BSSF can be significantly reduced. BSSF was an initial investigatory tool for evaluating contaminated waste products generated from drinking water filtration and examining slow sand filter bacteria removal efficiencies. Filtration rate influenced the contaminants removal effect in slow sand filtration, and more contaminants could be removed at lower filtration rates. The tendency of smaller particles to appear in the BSSF was therefore related to their lower destabilization rates during the coagulation process as well as their lower collision rates in the flocculation and filtration processes [33]. Removal of bacteria was found to depend strongly on the water temperature and Schmutzdecke age [34], whereas a change in filtration rate within the ranges as demonstrated here has a small effect on microorganism removal. The schmutzdecke to microorganism removal was based on the concept of temperature-dependent biological activity, and there is an association with attachment. The BSSF model currently does not include filter bed resistance, which is expected to affect BSSF performance. This will further ensure understanding of the filtration process and could lead to a database of retention factors and reaction rate coefficients to be used in predictive modeling of filter performance [9]. The method does not consider specific antimicrobial contaminant degradation by hydrolysis or interactions of antimicrobials with dissolved organic matter, and continued use and refinement of the BSSF model by drinking water research is greatly encouraged.

This will further ensure understanding of the filtration process and could lead to a database of retention factors and reaction rate coefficients to be used 
in predictive modeling of filter performance. The model could also be applied to bacteria removal from surface water in drinking water purification with SSFs. As studies characterizing the ecology of the SSF sand bed have used particle size, filling height, filtration rate and temperature without the ability to distinguish the main contribution of influencing factors, it is difficult to say which mechanisms within the sand bed ecosystem are responsible for effluent water quality.

\section{Conclusions}

Slow sand filtration is one of the earliest water treatment processes, and it usually has a continuous flow and sustainable mode of operation. This paper provides a basis for research on the optimal contaminant removal efficiency based on NBS. We optimized the important parameters of BSSF water treatment technology, such as the bio-filter material particle size and the filling heights, filtering velocity, and suitable temperature, by setting a comparative analysis of experimental tests to obtain the best design and operating parameters of BSSF water treatment technology based on NBS. The filter material had an optimum particle size of 0.3 to $0.6 \mathrm{~mm}$. The filter material filling height was optimally $0.6-0.9 \mathrm{~m}$. The filtration rate was optimally $0.2-0.6 \mathrm{~m} / \mathrm{h}$. The suitable temperature for the test was $15-35^{\circ} \mathrm{C}$. BSSF is an economical technique that requires less skilled manpower due to its simplicity. The results of this lab-scale test show that BSSF based on NBS is potentially an effective process for removing contaminants/microorganisms from synthetic wastewater.

\section{Acknowledgements}

Our study was financially supported by Peak Discipline Construction Project of Education at East China Normal University, the National Key Research and Development Program of China (2018YFC0408100 \& 2016YFC0401408), the Support Program for University Scientific and Technological Innovation Talents of Henan Province (16HASTIT024), and the National Social Science Foundation of China (grant No. 13AZD097).

\section{Conflict of Interest}

The authors declare no conflict of interest.

\section{References}

1. VAN DER KOOIJ D., VEENENDAAL H.R., VAN DER MARK E.J., DIGNUM M. Assessment of the microbial growth potential of slow sand filtrate with the biomass production potential test in comparison with the assimilable organic carbon method. Water Research 125, 270, 2017.

2. HUISMAN L., WOOD W.E. Slow Sand Filtration. World Health Organization, Belgium, Germany. 1974.

3. VAN DER KOOIJ D., MARTIJN B., SCHAAP P.G., HOOGENBOEZEM W., VEENENDAAL H.R., VAN DER WIELEN P.W.J.J. Improved biostability assessment of drinking water with a suite of test methods at a water supply treating eutrophic lake water. Water Res. 87, 347, 2015.

4. VAN LIEVERLOO J.H.M., HOOGENBOEZEM W., VEENENDAAL G., VAN DER KOOIJ D. Variability of invertebrate abundance in drinking water distribution systems in The Netherlands in relation to biostability and sediment volumes. Water Res. 46, 4918, 2012.

5. NEOH C.H., NOOR Z.Z., MUTAMIM N.S.A., LIM C.K. Green technology in wastewater treatment technologies: integration of membrane bioreactor with various wastewater treatment systems. Chem. Eng. J. 283, 582, 2016.

6. TYAGI V.K., KHAN A.A., KAZMI A.A., MEHROTRA I., CHOPRA A.K. Slow sand filtration of UASB reactor effluent: A promising post treatment technique. Desalination 249, 571, 2009.

7. PANNO A., CARRUS G., LAFORTEZZA R., MARIANI L., SANESI G. Nature-based solutions to promote human resilience and wellbeing in cities during increasingly hot summers. Environmental research 159, 249, 2017.

8. ZHANG J., ZHANG C.L., SHI W.L., FU Y.C. Quantitative evaluation and optimized utilization of water resourceswater environment carrying capacity based on naturebased solutions. Journal of Hydrology 568, 96, 2019.

9. LANGENBACH K., KUSCHK P., HORN H., KASTNER M. Modeling of slow sand filtration for disinfection of secondary clarifier effluent. Water research 44, 159, 2010.

10. POMPEI C.M.E., CIRIC L., CANALES M., KARU K., VIEIRA E.M., CAMPOS L.C. Influence of PPCPs on the performance of intermittently operated slow sand filters for household water purification. Science of the Total Environment 581-582, 174, 2017.

11. HAIG S.J., QUINCE C., DAVIES R.L., DOREA C.C., COLLINS G. Replicationg the microbial community and water quality performance of full-scale filters in laboratory-scale filters. Water Res. 61, 141, 2014.

12. HWANG H.G., KIM M.S., SHIN S.M., HWANG C.H. Risk assessment of the Schmutzdecke of bio sand filters: identification of an opportunistic pathogen in schmutzdecke developed by an unsafe water source. Int. J. Environ. Res. Public Health 11, 2033, 2014.

13. TIAN J.Y., ERNST M., CUI F., JEKEL M. Effect of particle size and concentration on the synergistic UF membrane fouling by particles and NOM fractions. J. Membr. Sci. 446, 1, 2013.

14. BUCHTA P., KRIPAHLE A., VIAL D., WINKLER R., BERG P. In-out ultrafiltration in tertiary wastewater applications - comparison of different operational strategies. Desalin. Water Treat. 73, 145, 2017.

15. RAUCH-WILLIAMS T., DREWES J.E. Using soil biomass as an indicator for the biological removal of effluent-derived organic carbon during soil infiltration. Water Res. 40, 961, 2006.

16. PELDSZUS S., HALLE C., PEIRIS R.H., HAMOUDA M., JIN X., LEGGE R.L., BUDMAN H., MORESOLI C., HUCK P.M. Reversible and irreversible low-pressure membrane foulants in drinking water treatment: 
identification by principal component analysis of fluorescence EEM and mitigation by biofiltration pretreatment. Water Res. 45, 5161, 2011.

17. DULLEMONT Y.J., SCHIJVEN J.F. Removal of microorganisms by slow sand filtration, in recent progress in slow sand and alternative biofiltration processes. IWA Publishing, London, UK, 12, 2006.

18. SCHIJVEN J.F.A., VAN DEN BERG H.H.J.L., COLIN M., DULLEMONT Y., HIJNEN W.A.M., MAGICKNEZEV A. A mathematical model for removal of human pathogenic viruses and bacteria by slow sand filtration under variable operational conditions. Water research $\mathbf{4 7}$, 2592, 2013.

19. TERIN U.C., SABOGAL-PAZ L.P. Microcystis aeruginosa and microcystin-LR removal by household slow sand filters operating in continuous and intermittent flows. Water Research 150, 29, 2019.

20. BAUER R., DIZER H., GRAEBER I., ROSENWINKEL K.-H., LO'PEZ-PILA J.M. Removal of bacterial fecal indicators, coliphages and enteric adenoviruses from waters with high fecal pollution by slow sand filtration. Water research 45, 439, 2011.

21. GUO Y.Q., BAI L.M., TANG X.B., HUANG Q.J., XIE B.H., WANG T.Y., WANG J.L., LI G.B., LIANG H. Coupling continuous sand filtration to ultrafiltration for drinking water treatment: Improved performance and membrane fouling control. Journal of Membrane Science 567, 18, 2018.

22. MOREIRA NETO R.F., CALIJURI M.L., CARVALHO I.D.C., SANTIAGO A.D.F. Rainwater treatment in airports using slow sand filtration followed by chlorination: Efficiency and costs. Resources, Conservation and Recycling 65, 124, 2012.

23. HIJNEN W.A.M., SCHIJVEN J.F., BONNE P., VISSER A., MEDEMA G.J. Elimination of viruses, bacteria and protozoan oocysts by slow sand filtration. Water Science \& Technology 50, 147, 2004.

24. HAIG S.J., COLLINS G., DAVIES R.L., DOREA C.C., QUINCE C. Biological aspects of slow sand filtration: past, present and future. Water Sci. Technol. 11, 468, 2011.

25. YAO K.M., HABIBIAN M.T., O'MELIA C.R. Water and waste water filtration: concepts and applications. Environmental Science \& Technology 5, 1105, 1971.

26. TUFENKJI N., ELIMELECH M. Deviation from the classical colloid filtration theory in the presence of repulsive DLVO interactions. Langmuir 20, 10818, 2004.

27. MEHLE N., RAVNIKAR M. Plant viruses in aqueous environment-survival, water mediated transmission and detection. Water Res. 46, 4902, 2012.

28. YOUNKER J.M., WALSH M.E. Effect of adsorbent addition on floc formation and clarification. Water Res. 98, $1,2016$.

29. LI J.N, ZHOU Q.Z., CAMPOS L.C. The application of GAC sandwich slow sand filtration to remove pharmaceutical and personal care products. Science of the Total Environment 635, 1182, 2018

30. LEE E., OKI L.R. Slow sand filters effectively reduce Phytophthora after a pathogen switch from Fusarium and a simulated pump failure. Water research 47, 5121, 2013.

31. POMPEI C.M.E., CIRIC L., CANALES M., KARU K., VIEIRA E.M., CAMPOS L.C. Influence of PPCPs on the performance of intermittently operated slow sand filters for household water purification. Science of the Total Environment 581-582, 174, 2017.

32. HELMREICH B, HORN H. Opportunities in rainwater harvesting. Desalination 245, 118, 2009.

33. NAKAZAWA Y., MATSUI Y., HANAMURA Y., SHINNO K., SHIRASAKI N., MATSUSHITA T. Identifying, counting, and characterizing superfine activated-carbon particles remaining after coagulation, sedimentation, and sand filtration. Water Research 138, 160, 2018.

34. ELLIOTT M.A., DIGIANO F.A., SOBSEY M.D. Virus attenuation by microbial mechanisms during the idle time of a household slow sand filter. Water Research 45, 4092, 2011. 
